\title{
ANALYSIS OF THE CAVEBATH OF MISKOLCTAPOLCA'S BRAND ELEMENTS AND GUESTS SATISFACTION
}

\author{
${ }^{1}$ Müller Anetta $-{ }^{2}$ Boda Eszter Judit $-{ }^{3}$ Ráthonyi Gergely $-{ }^{4}$ Ráthonyi-Odor Kinga - \\ ${ }^{5}$ Barcsák Barbara - ${ }^{6}$ Könyves Erika $-{ }^{7}$ Bíró Melinda $-{ }^{8}$ Beáta Dobay- ${ }^{9}$ Elena Bendíkova \\ 1,2,5,7 University of Karoly Eszterhazy, Department of Sportmanagement and Recreation \\ University of Debrecen, e-mail: muller@ektf.hu, boda.eszter@ektf.hu, barbi4682@gmail.com, biromelinda@ektf.hu \\ 3Department of Agricultural Informatics, e-mail: rathonyi.gergely@econ.unideb.hu \\ ${ }^{4}$ Department of Sporteconomics and Management, e-mail: rathonyi-odor.kinga@econ.unideb.hu \\ ${ }^{6}$ Department of Tourism and Catering Management, e-mail: konyves.erika@econ.unideb.hu \\ ${ }^{8}$ University of Janos Selye, e-mail: dobayb@ujs.sk \\ ${ }^{9}$ University of Matyas Bel, e-mail: elena.bendikova@umb.sk
}

\begin{abstract}
In the region of Northern Hungary the unique Cavebath of Miskolcatapolca is one of the leading health tourism service positioning itself on national and international market with its developing supply items and 4 star qualifications. It has a unique natural background all over in Europe; this uniqueness gives an opportunity to develop brand, which is a determinative item of competitiveness.

Because of the competition between destinations and the ever-changing nature of tourists' expectations and behavior tourism destinations need to be managed as other commercial brands.

The aim of our research was to analyze the role and possibilities of product development which is based on the unique natural factors, and to help to expand the domestic health tourism supply. We examined how the possibility of branding and brand equity change based on brand elements; how satisfied are guests with the services; how often guests visit the bath; what kind of period guests arrive in the bath; what kind of services do guests try; how do guests arrive in the bath with.

In summer of 2014 we asked 210 Hungarian customers to fill the questionnaire in the Cavebath. The choosing of guests happened randomly. 199 questionnaires were correctly filled.
\end{abstract}

Keywords: Northern Hungary, Cavebath of Miskolctapolca, guests satisfaction, brand elements (JEL CODE: Z32)

\section{INTRODUCTION}

Tourism industry is one of the most dynamically developing branch of the world. According to the results of the research made by WTTC (2015) tourism gives $9.8 \%$ of the GDP of the world with multiplicator effects. This branch results 276 million jobs all over the world which means $9.4 \%$ of all employment. The economical forecasts show that tourism is income generator and job creator and these effects are going to increase in the future.

The number of tourist arrivals is increasing almost unabated year by year since 2000. Exception is 2009, when the economic crisis resulted decrease in the number of tourist arrivals around the world, however, by 2010 it showed sales growth again. In 2012 the number of tourist arrivals reached 1 billion. In 2014 the number of international tourist arrivals increased with 5\% compared to the year before, which meant 1 billion and 133 million person arrivals all over the world (UNWTO 2015). In our country the international tourist turnover increment $(13,7 \%)$ was more dynamical in 2014 compared to the world average (5\%), which showed the 4. largest growth in Europe. However the territory of Europe (10,5 million $\mathrm{km}^{2}$ ) gives only $7 \%$ of all continents, though half $(51,4 \%)$ of the tourist arrivals so 581,8 million arrival is realized in Europe. $80 \%$ of tourist arrivals choose EU member country for destination. In 2015 the number of tourist arrivals show further increase, which today reached and exceeded the number of 1,2 billion people (UNWTO 2016).

In our country health tourism is developmental priority for a long time. In The New Széchenyi plan (2011) of the Remedial 
Hungarian-Health Industry program the developing is bipolar, one of them is built on the development of health tourism, other one is the development of thermal-health industry.

The justification of the innovation of baths are confirmed by the rich stock of thermal water, which can be found at $80 \%$ of the territory of our country, so it is the most important medical factor.

More and more national and international researches deal with bath developments and health tourism investments (Barta et al. 2011; Borbély and Müller 2008; Kerényi et al. 2010; Könyves et al. 2005; Mosonyi et al. 2010; Müller and Kórik 2009; Müller and Szabó 2009; Nemoda et al. 2011; Nemoda et al. 2012). In Slovakia bath tourism, which is an element of health tourism, also goes through grand developments, as it gives advance to the habitants here (Bánhidi 2011; Dobay and Bánhidi 2012; Dobay and Bendikova 2014;). In the last decades the continuous developments of health tourism resulted that our country's competition improved on the market of health tourism. The expansion of the capacity of accommodations and the qualitative developments improved the conditions of tourist reception. Thanks to improvements in the capacity of baths (with the increasing of the water surface), the expansion of the supply elements, the enrichment of surrounding and design, the wide repertoire of free-time activities, employing animators can satisfy the growing demand of health tourism at a European standard (Barcsák 2014).

Thermal water is one of the most significant facilities in the region of Northern Hungary. Thermal water can mean a chance in the competition of tourism destinations for several settlements.

In the region of Northern Hungary the unique Cavebath of Miskolcatapolca is one of the leading health tourism service positioning itself on national and international market with its developing supply items and 4 star qualifications. It has a unique natural background all over in Europe; this uniqueness gives an opportunity to develop brand, which is a determinative item of competitiveness.

Because of competition between destinations and the everchanging nature of tourists' expectations and behavior tourism destinations need to be managed as other commercial

brands. The brand image plays a crucial role in the success of destinations and has a significant influence on customer behavior (Mosonyi et al. 2013). Tourists visiting a destination for the first time are more likely to choose one which has a powerful, positive, unique, easily recognizable image (Beerli and Martín, 2004).

Thus, brand and a unique image significantly influence destination selection. A brand is a "Name, term, design, symbol, or any other feature that identifies one seller's good or service as distinct from those of other sellers" (Kotler 1999). Today it is very important that Hungary should be able to create, based on our special characteristics, a strong brand which makes us distinct from all our competitors on the increasingly competitive global tourism market.

Other definition: products or services which offer a useful and unique set of features in a standardized form and the same quality (Horkay 2003). This definition puts the customer, the fulfillment of the customer's needs and the quality parameters of the products and services. Brand policy communicates recognizable achievements which are unique to the company and can be recognized from time to time again. (Bruhn 1944). A good example for brand policy are the successful hotel chains (Danubius, Hilton, etc.) which emphasize easily recognizable company specific features in their marketing. In many cases,customers do not simply buy a product, they buy a brand. Customers and guests attach an expected quality to the brand, consequently brands delivering the biggest customer satisfaction will be the most successful ones on the market. Purchasing decisions are not always made in favour of the provider offering the highest quality services, price-service ratio can be a more significant factor (Scherlag 2000).

As any other brand, destination brands aim to form a distinctive image that is recognizable and can be differentiated from rival destinations (Horkay 2003).

In the domestic and international competition of destinations only those regions and laces are successful which focus on the experience of the most successful international destinations (benchmarking) and combine their innovative, quality-centered tourism product development with consistent positioning and differentiating strategy. Professional brand policy in tourism (brand creation and management) is the competitive means to create a unique product portfolio. It is a break-out point and a strategic task for the management of every destination: lasting success is guaranteed only by possessing a brand which cannot be confused or replaced by other brands, a brand that has an appeal, invokes emotions and has a strong enough reputation. (Horkay, 2003)

- In our study we try to answer the following questions:

- How the possibility of branding and brand equity changes based on the brand elements?

- How satisfied are guests with the services?

- How often guests visit the bath?

- What kind of period guests arrive in the bath?

- What kind of services do guests try?

- How do guests arrive in the bath with?

In this study we analyzed the justification of the next hypotheses:

H1: Due to the spa is under continuous improvement it affects the satisfaction of guests and the evaluation of brand elements of the spa.

H2: The tourism brand system of the spa has to include those important values and activities that the tourists can refer to the spa and differentiate the spa from other spa-destinations. H3: The strong brand of the spa positively affects the performance of tourism service providers and SMEs of the destination. The tourism brand and product development that based on standardized brand increases the competitiveness of tourism SMEs with low innovation potential in the destination. H4: Probably the guests will be satisfied with services. The guests with lower educational attainment will be more satisfied with the services.

H5: We presume that inhabitants of Miskolc mostly visit the bath in the afternoon, as they do not require longer relaxation as their homes are close.

H6: Most of the respondents heard about Cavebath by hearsay 
then from the internet.

H7: Most of guests arrive in the bath with their friends.

\section{MATERIAL AND METHODS}

In summer of 2014 we asked 210 Hungarian customers to fill the questionnaire in the Cavebath. The choosing of guests happened randomly. 199 questionnaires were correctly filled.

In the questionnaires used in the baths there were both open and closed questions (19 items). Part of the questions were put into the question group concerning quality assessment of the baths. Guest satisfaction was measured through the provided services, the work of the staff, etc. There were questions about how satisfied they were with the opening hours, the work of staff, the price/value ratio of services, the choice of services, the quality of services including cleanliness of pools and their design elements. Answers to these questions were scaled between $1-5$ scale $(1=$ not satisfied at all, $2=$ not very satisfied, $3=$ fairly satisfied, $4=$ satisfied, $5=$ very satisfied).

An average was calculated from the results showing the overall assessment of baths by the guests. The main question groups as referred to above:

- questions about guests' familiarity with information such as prices, services, marketing activity, water composition etc.

- questions about factors affecting bath choice such as number of pools, design of bath, etc.

- questions about the symbols and associations concerning the bath such as thoughts and feelings induced by the bath and the time spent there, experience with water, experience with slides etc.

Questions were rated by guests on a 1-5 scale and the average values of the different brand elements were displayed on graphs. Data was processed with SPSS 20.0 statistical software.

\section{RESULT AND DISCUSSION}

During the survey we created the next age groups:

1. from the lowest age to age of 24 (youngsters)

2. -age 25-34 (young adults)

3. -age 35-59 (middle aged)

4. over the age of 60 (elders)

The dispersion of different age groups in the sample is shown in Table 1. From the examined 199 guests 116 were women and 86 were men.

Table 1.: The dispersion of the sample according to age groups

\begin{tabular}{|c|c|c|}
\hline Age Group & Responder (person) & Responder (\%) \\
\hline Youngsters & 51 & 25.63 \\
\hline Young adults & 52 & 26.13 \\
\hline Middle aged & 82 & 41.21 \\
\hline Elders & 14 & 7.04 \\
\hline Total & $\mathbf{1 9 9}$ & $\mathbf{1 0 0 . 0}$ \\
\hline
\end{tabular}

Source: own composition
In the questionnaires there were questions about the reputation of the bath and the connection between reputation and travel decision.

Questions about customer satisfaction were focused on: choice of products, prices, cleanliness of the bath and its environment, design elements of pools, hospitality of local people, opening hours, quality of service provided by staff, prices of tickets and the price-value ratio, programs offered by the bath and children friendly services. An average was calculated from the data to show quality. Other questions were aimed at symbols of the bath and its attraction elements. Several unique features of the baths were specified by participants. Examination of brand elements clearly shows that the Cavebath of Miskolctapolca has a well-established brand.

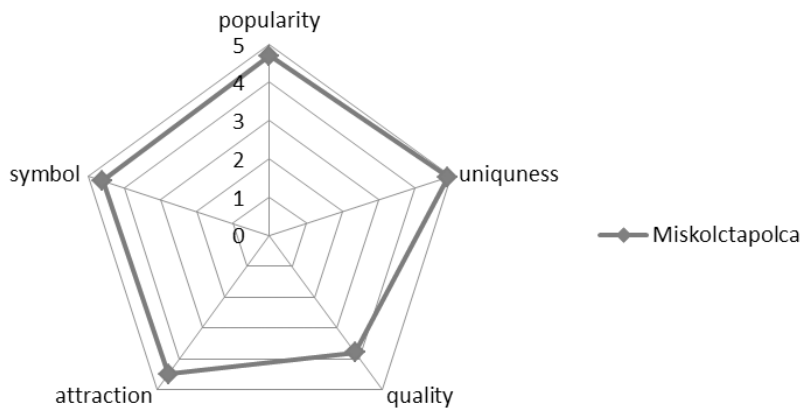

Figure 1: Brand system of Cavebath of Miskolctapolca Source: own composition

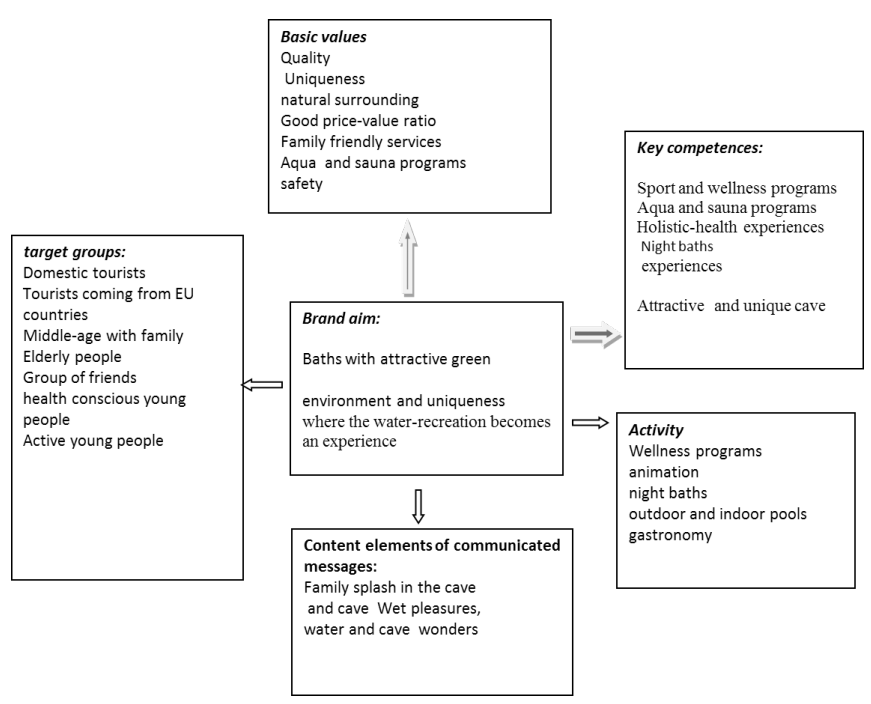

Figure 2.: Branding potential of Cavebath of Miskolcatpolca Source: own composition

The Miskolctapolca umbrella brand contains brand aims, basic values, activities, key competencies, communicated messages and main target groups to which all domestic baths have to conform when developing their individual brands (Müller et al. 2016). The results confirmed our hypotheses.

After this, we analyzed the satisfaction with services according to educational attainment. 
We assumed correlation in connection with satisfaction and educational attainment; accordingly, guests with lower education will be more satisfied with the provided services. After $\mathrm{chi}^{2}$ test we could not find a significant difference $(\mathrm{p}>$ 0.05). This hypothesis was not confirmed which can be seen in Table 2.

Table 2: Satisfaction with services according to educational attainment

\begin{tabular}{|l|c|c|c|c|c|c|}
\hline $\begin{array}{l}\text { What is } \\
\text { your high- } \\
\text { est level of } \\
\text { education? }\end{array}$ & $\begin{array}{c}\text { not } \\
\text { satis- } \\
\text { fied(\%) }\end{array}$ & $\begin{array}{c}\text { rather } \\
\text { satisfied } \\
(\%)\end{array}$ & $\begin{array}{c}\text { mod- } \\
\text { erately } \\
\text { satis- } \\
\text { fied(\%) }\end{array}$ & $\begin{array}{c}\text { satisfied } \\
(\%)\end{array}$ & $\begin{array}{c}\text { totally } \\
\text { satisfied } \\
(\%)\end{array}$ & $\begin{array}{c}\text { Total } \\
(\%)\end{array}$ \\
\hline $\begin{array}{l}\text { Elemen- } \\
\text { tary school } \\
\text { or lower }\end{array}$ & 5.00 & 10.00 & 20.00 & 45.00 & 20.00 & 100.00 \\
\hline & 25.00 & 18.18 & 10.81 & 8.41 & 10.00 & 10.05 \\
\hline $\begin{array}{l}\text { Vocational } \\
\text { training }\end{array}$ & 0.50 & 1.01 & 2.01 & 4.52 & 2.01 & 10.05 \\
\hline & 5.56 & 0.00 & 25.00 & 63.89 & 5.56 & 100.00 \\
\hline $\begin{array}{l}\text { High / } \\
\text { Secondary } \\
\text { school }\end{array}$ & 1.45 & 5.80 & 20.29 & 49.28 & 23.19 & 100.00 \\
\hline & 25.00 & 36.36 & 37.84 & 31.78 & 40.00 & 34.67 \\
\hline & 0.50 & 2.01 & 7.04 & 17.09 & 8.04 & 34.67 \\
\hline $\begin{array}{l}\text { Univer- } \\
\text { sity/Col- } \\
\text { lege }\end{array}$ & 0.00 & 6.94 & 13.89 & 54.17 & 25.00 & 100.00 \\
\hline & 0.00 & 45.45 & 27.03 & 36.45 & 45.00 & 36.18 \\
\hline Other & 0.00 & 0.00 & 0.00 & 100.00 & 0.00 & 100.00 \\
\hline & 2.00 & 0.00 & 0.00 & 1.87 & 0.00 & 1.01 \\
\hline & 0.00 & 0.00 & 1.01 & 0,00 & 1.01 \\
\hline & 5.53 & 18.59 & 53.77 & 20,10 & 100.00 \\
\hline & 100.00 & 100.00 & 100.00 & 100.00 & 100.00 & 100.00 \\
\hline & 5.53 & 18.59 & 53.77 & 20.10 & 100.00 \\
\hline
\end{tabular}

With the following question we analyzed how often guests visit bath? (Table 3.)

Table 3.: Frequency of visiting bath according to place of habitat

\begin{tabular}{|l|c|c|c|c|c|c|}
\hline $\begin{array}{l}\text { Place of } \\
\text { habitat?- } \\
\text { Miskolc }\end{array}$ & Daily & $\begin{array}{c}\text { Regularly } \\
\text { (several } \\
\text { times a } \\
\text { week) }(\%)\end{array}$ & $\begin{array}{c}\text { Weekly } \\
(\%)\end{array}$ & Monthly & $\begin{array}{c}\text { A few } \\
\text { times a } \\
\text { year }(\%)\end{array}$ & Total \\
\hline $\begin{array}{l}\text { Inhabitant } \\
\text { of Miskolc }\end{array}$ & 1.37 & 4.11 & 5.48 & 43.84 & 45.21 & 100.00 \\
\hline & 100.00 & 75.00 & 26.67 & 55.17 & 27.27 & 36.68 \\
\hline & 0.50 & 1.51 & 2.01 & 16.08 & 16.58 & 36.68 \\
\hline $\begin{array}{l}\text { Other } \\
\text { inhabitant }\end{array}$ & 0.00 & 0.79 & 8.73 & 20.63 & 69.84 & 100.00 \\
\hline & 0.00 & 25.00 & 73.33 & 44.83 & 72.73 & 63.32 \\
\hline & 0.00 & 0.50 & 5.53 & 13.07 & 44,22 & 63.32 \\
\hline Total & 0.50 & 2.01 & 7.54 & 29.15 & 60.80 & 100.00 \\
\hline & 100.00 & 100.00 & 100.00 & 100.00 & 100.00 & 100.00 \\
\hline & 0.50 & 2.01 & 7.54 & 29.15 & 60.80 & 100.00 \\
\hline
\end{tabular}

According to these results the inhabitants of Miskolc visit the bath more often, than the guests who arrive from a far distance. This also means that visiting the bath for local residents is a recreational plug-activity, while for visitors from a distance it is an infiltrated tourist motivation, as choosing destination is the motivation.

We found it interesting to examine what kind of period guests arrive in the bath?

According to Table 4., the inhabitants of Miskolc arrive to the bath in the afternoon, those who are not inhabitants of Miskolc prefer to buy all day ticket. Results confirmed our hypothesis.

Table 4.: Periodical visiting of the bath according to place of habitat

\begin{tabular}{|l|c|c|c|c|c|c|}
\hline & $\begin{array}{c}\text { In the } \\
\text { morning } \\
\text { hours } \\
\text { habitat } \\
(\%)\end{array}$ & $\begin{array}{c}\text { In the } \\
\text { forenoon } \\
(\%)\end{array}$ & At noon & $\begin{array}{c}\text { In the } \\
\text { after- } \\
\text { noon }\end{array}$ & $\begin{array}{c}\text { In the } \\
\text { evening } \\
\text { hours } \\
(\%)\end{array}$ & Total \\
$(\%)$ & $(\%)$ \\
\hline $\begin{array}{l}\text { Inhabitant } \\
\text { of Miskolc }\end{array}$ & 12.33 & 31.51 & 15.07 & 36.99 & 4.11 & 100.00 \\
\hline & 40.91 & 27.38 & 39.29 & 45.76 & 50.00 & 36.68 \\
\hline & 4.52 & 11.56 & 5.53 & 13.57 & 1.51 & 36.68 \\
\hline $\begin{array}{l}\text { Other in- } \\
\text { habitant }\end{array}$ & 10.32 & 48.41 & 13.49 & 25.40 & 2.38 & 100.00 \\
\hline & 59.09 & 72.62 & 60.71 & 54.24 & 50.00 & 63.32 \\
\hline & 6.53 & 30.65 & 8.54 & 16.08 & 1.51 & 63.32 \\
\hline Total & 11.06 & 42.21 & 14.07 & 29.65 & 3.02 & 100.00 \\
\hline & 100.00 & 100.00 & 100.00 & 100.00 & 100.00 & 100.00 \\
\hline & 11.06 & 42.21 & 14.07 & 29.65 & 3.02 & 100.00 \\
\hline
\end{tabular}

Our next question was, how often guests visit the bath? Table 5. shows, that it can be considered that young adults visit baths more often, than older.

Table 5.: Frequency of visiting bath according to age groups

\begin{tabular}{|l|c|c|c|c|c|c|}
\hline $\begin{array}{l}\text { Age } \\
\text { group }\end{array}$ & Daily & $\begin{array}{c}\text { Regularly } \\
(\text { several } \\
\text { times a } \\
\text { week) (\%) }\end{array}$ & $\begin{array}{c}\text { Weekly } \\
(\%)\end{array}$ & $\begin{array}{c}\text { Month- } \\
\text { ly (\%) }\end{array}$ & $\begin{array}{c}\text { A few times } \\
\text { a year(\%) }\end{array}$ & $\begin{array}{c}\text { Total } \\
(\%)\end{array}$ \\
\hline $\begin{array}{l}\text { Young- } \\
\text { sters }\end{array}$ & 0.00 & 1.96 & 3.92 & 29.41 & 64.71 & 100.00 \\
\hline & 0.00 & 25.00 & 13.33 & 25.86 & 27.27 & 25.63 \\
\hline & 0.00 & 0.50 & 1.01 & 7.54 & 16.58 & 25.63 \\
\hline $\begin{array}{l}\text { Young } \\
\text { adults }\end{array}$ & 0.00 & 3.85 & 7.69 & 42.31 & 46.15 & 100.00 \\
\hline & 0.00 & 50.00 & 26.67 & 37.93 & 19.83 & 26.13 \\
\hline & 0.00 & 1.01 & 2.01 & 11.06 & 12.06 & 26.13 \\
\hline $\begin{array}{l}\text { Middle } \\
\text { aged }\end{array}$ & 1.22 & 1.22 & 8.54 & 21.95 & 67.07 & 100.00 \\
\hline & 100.00 & 25.00 & 46.67 & 31.03 & 45.45 & 41.21 \\
\hline & 0.50 & 0.50 & 3.52 & 9.05 & 27.64 & 41.21 \\
\hline Elders & 0.00 & 0.00 & 14.29 & 21.43 & 64.29 & 100.00 \\
\hline & 0.00 & 0.00 & 13.33 & 5.17 & 7.44 & 7.04 \\
\hline & 0.00 & 0.00 & 1.01 & 1.51 & 4.52 & 7.04 \\
\hline Total & 0.50 & 2.01 & 7.54 & 29.15 & 60.80 & 100.00 \\
\hline & 100.00 & 100.00 & 100.00 & 100.00 & 100.00 & 100.00 \\
\hline & 0.50 & 2.01 & 7.54 & 29.15 & 60.80 & 100.00 \\
\hline
\end{tabular}


Table 6. represents the result of analysing marketing activity. (How did you hear about Cavebath?)

Table 6.: Analysing marketing activity

\begin{tabular}{|l|c|c|c|c|}
\hline $\begin{array}{l}\text { An- } \\
\text { swers }\end{array}$ & $\begin{array}{c}\text { Frequency } \\
(\mathrm{pc})\end{array}$ & $\begin{array}{c}\text { Distribution } \\
(\%)\end{array}$ & $\begin{array}{c}\text { Current } \\
\text { distribution (\%) }\end{array}$ & $\begin{array}{c}\text { Cumulated } \\
\text { value (\%) }\end{array}$ \\
\hline $\begin{array}{l}\text { News- } \\
\text { paper }\end{array}$ & 10 & 5.03 & 5.03 & 5.03 \\
\hline $\begin{array}{l}\text { Televi- } \\
\text { sion }\end{array}$ & 9 & 4.52 & 4.52 & 9.55 \\
\hline Internet & 66 & 33.17 & 33.17 & 42.71 \\
\hline Hearsay & 113 & 56.78 & 56.78 & 99.50 \\
\hline & 1 & 0.50 & 0.50 & 100.00 \\
\hline Total & 199 & 100.0 & 100.0 & \\
\hline
\end{tabular}

Results show that the most important information source about the bath is hearsay information. Every third respondent searches information about the bath on internet, while only $5 \%$ of respondents use traditional information sources during the information searching process. These results also reveal the fact that word of mouth information and fellow travelers' recommendations have a huge impact on tourist decisions (Ráthonyi 2013). Due to the widespread of internet, social media, developed information and communication technologies the importance of traditional information sources have decreased.

Our next question was: would you recommend the bath to your friends, acquaintances, family? 98,5\% (196 persons) of respondents would recommend the bath to others, which is an important sign of satisfaction.

Table 7. shows that most of the respondents arrive with their friends, which confirmed our hypothesis. Others arrive with mate, sibling or parent, which shows the dominance of family audience. We can see that "groups of friends" also has a high percentage. So bath satisfies the recreational and tourist motivation of families, but is suitable for group of friends as a free time activity as well.

Table 7.: Who do you arrive to the bath with?

\begin{tabular}{|l|c|c|}
\hline & Number of guests & $\%$ \\
\hline Alone & 17 & 8.5 \\
\hline With mate & 118 & 19.3 \\
\hline With parent & 40 & 20.1 \\
\hline With sibling & 31 & 15.6 \\
\hline With friends & 66 & 33.2 \\
\hline Other & 49 & 24.6 \\
\hline
\end{tabular}

Next, we analysed services used by guests (Table 8.).
Table 8.: Services used by guests

\begin{tabular}{|l|c|c|}
\hline & Number of guests & $\%$ \\
\hline Outdoor pools & 152 & 76.4 \\
\hline Indoor pools & 174 & 87.4 \\
\hline Sauna park and solarium & 51 & 25.6 \\
\hline Sauna seance & 26 & 13.1 \\
\hline Aqua fitness & 21 & 10.6 \\
\hline Night bath & 35 & 17.6 \\
\hline Creative playing noor & 4 & 2.0 \\
\hline Baby-Mommy corner & 2 & 1.0 \\
\hline Giftshop & 5 & 2.5 \\
\hline Coctail bar and grill terrace & 12 & 6.0 \\
\hline Thermal restaurant & 74 & 37.2 \\
\hline
\end{tabular}

Suitably to the bath profile the indoor and outdoor pools attract visitors mostly, as they use these services most often. Cavebath is attractive for the guests because of its unique appearance, so by the cave pools, as it is preferred the most even in the summer period. The other popular services among the guests are the restaurant $(37,2 \%)$, the sauna park $(25,6 \%)$, and night bathing $(17,6 \%)$.

\section{Results of the correlation study}

We examined the correlation among genders, age, educational attainment and place of residence. We found significant difference in the next ones:

Beach and waterpark are preferred by youngsters (10-24) and young adults (25-34), more than middle aged and elders $\left(\mathrm{chi}^{2}=63,68, \mathrm{p}=0,008\right)$.

Living aquatic bath is also preferred by youngsters and young adults $\left(\mathrm{chi}^{2}=53.42, \mathrm{P}=0,004\right.$.

Spa is preferred by middle aged and elders $\left(\mathrm{chi}^{2}=64,04\right.$, $\mathrm{p}=0,019)$.

Among programs aquafitness is preferred mainly by women in contrast with men $\left(\mathrm{chi}^{2}=4.82, \mathrm{P}=0.037\right)$.

\section{CONCLUSION}

Product development is essential nearly for every bath. Visiting bath is infiltrated into everyday programs, with the expanding of supplied elements it is a good opportunity for connecting regular exercising, body care and relaxing. Accordingly, the baths are the scene of body and soul care, maintaining social well-being and health. Guests, who regularly visiting baths, expect ordinary free time services and high quality of services which indicates that baths of tourist destinations have to take these factors into consideration during product development.

It is recommended to evolve brand. Thanks to the changes in tourism, the competition between products and destinations, the conformation of expectations of tourists and the changes of their habits tourist destinations should be treated as a trade brand. The image of the brand has a huge importance in connection with the success of a tourist destination, which has a great influence on the consumer's behavior. Those tourists who visit a tourist 
destination for the first time and have limited information about the given place, will chose those "new" destinations with a bigger chance, which have powerful, positive, unique and well recognizable image. So brand and unique identity will have a significant influence on selecting a tourist destination.

Based on the analysis of brand components it is confirmed that the spa possesses a well-formed strong brand.

However the spa owns substantive, separable and identifiable brand components, its brand considering all brand elements can be handled as "average good" or "excellent". The reputation of the spa should be increased through the boost of individuality and the increase of attraction. Web-page development and merchandising would be great marketing communication tools to promote the brand equity of the spa.

It is also important to improve the web pages of the baths. Thanks to the swift growth of tourist sector advanced technologies are required to face the growing requirement of tourism. Tourism companies have to aspire for being aware of the latest technological trends and changes. There are several new technological innovations in the tourism industry which appeared or going to appear in the near future such as new mobile technologies, tracking technologies, new smart devices, new social media tools, new sensors (NFC, RFID) (Ráthonyi et al. 2016).

National and international researches also emphasize the development of human resource (Bácsné 2013). It is essential to employ animators as guests require personal care, that an animator can ensure for them. Many times this personal bonding is in the background of visitors return.

Our research revealed that a lot of families visit the Cavebath, there are many children here, as it is a multigeneral bath, which indicates that adult and children animator programs are essential. Especially in the summer period, but periodically or even all year it would be required by the guests visiting the bath.

\section{REFERENCES}

Barcsák B. (2014): Észak-magyarországi régió egészségturizmusa. Eszterházy Károly Fơiskola, Szakdolgozat

Barta G. - Pálinkás R. - Müller A. (2011): The Role of the Saliris Thermal Spa's bath in the tourism and recreation. Acta Academiae Agriensis Nova Series Tom-Sectio Sport Nr. 38. pp. 5-13.

Bácsné B. B. (2013): Hogyan növelhető a menedzserek személyes hatékonysága. A Virtuális Intézet Közép-Európa Kutatására Közleményei V.évf.1.:(A-sorozat 4.) 134. p.

Bánhidi M. (2011): Sportföldrajz, Dialóg Campus Pécs, ISBN 978963 9950, 223.p.

Beerli, A. -. Martín, J. D. (2004): Tourists' characteristics and the perceived image of tourist destinations: a quantitative analysis-a case study of Lanzarote. Tourism Management, Vol 25. No.5. pp. 623-636.

Borbély A. - Müller A. (2008): A testi-lelki harmónia összefüggései és módszertana. Valóság-Térkép-6. PEM tanulmányok 211.p.

Bruhn, M. (1994): Markenpolitik, Diller 640. p.

Dobay, B. - Bánhidi, M. (2012): Sport tourism development in Slovakia. Palestrica of the third millennium civilization and sport. Vol. 3 Nr.1. pp. 19-22.
Dobay, B. - Bendíková, E.: Športové a rekreačné aktivity v životnom štýle dospelých, Exercitatio Corporis-Motus-Salus Vol. 6. Nr. 2. pp. 19-31.

Horkay N. (2003): Turisztikai márka és márkapolitika a desztináció menedzsmentben II. Turizmus Bulletin Vol. 1. pp. 21-30.

Kerényi E. - Müller A. - Szabó R. - Mosonyi A. (2010): Bath Research in the Transdanubian Region in Hungary. Gazdasági élet és társadalom. I-II. pp. 164-173.

Kotler, P. (1999): Marketing menedzsment. Múszaki Könyvkiadó 491.p.

Könyves E. - Müller A. - Szalay F. - Szabó R. (2005):Cserkeszőlő és Karcag egészség-turizmusának összehasonlító elemzése. Szolnoki Tudományos Közlemények IX. (cd)

Mosonyi A. - Könyves E. - Kerényi E. - Müller A. (2010): Miskolctapolca egészségturizmusa egy vizsgálat tükrében. International Conference of Tourism, Recreation and Sports Management kiadványkötete (cd) 8.p.

Mosonyi A. - Lengyel A. - Müller A. (2013):Branding potential of spas in the Northern Plain and the Mid-Transdanubian Regions. APSTRACT. Vol.4-5. pp. 97-100.

Müller A. - Kórik V. (2009): Az Észak-alföldi fürdők szerepe a turizmusban és a rekreációban. Economica Vol. 2. pp. 58-72.

Müller, A. - Szabó, R. (2009): Analysis of Agárd, Komárom and Papa's Thermal Bath, According the Guest's satisfaction. Acta Academiae Pedagogicae Agriensis. XXXVI. pp. 89-101.

Müller, A. -Barcsák, B. - Boda, E. J. (2016): Health tourism the cavebath of Miskolctapolca In: Juhász, Gy. - Korcsmáros, E. - Huszárik, E. (ed.): Korszerû szemlélet a tudományban és az oktatásban. Zborník medzinárodnej vedeckej konferencie Univerzity J. Selyeho - 2016 „Súcasné aspekty vedy a vzdelávania”. Sekcie ekonomických vied. 278 p.

Nemoda M. - Szabó-Zimányi I. - Gazsi J. - Kiss Tóth E. - Szántó Á. (2011): A gyógyfürdők múltja és jelene az egészségturizmus szemszögéből. Geotudományok: A Miskolci Egyetem Közleménye: A Sorozat Bányászat Nr. 81. pp. 133-143.

Nemoda M. - Szántó Á. - Barkai L. (2012): Orvosi szolgáltatásokon alapuló önkéntes betegmobilitás lehetőségei Magyarország számára. Egészségtudományi Közlemények: A Miskolci Egyetem Közleménye Vol. 2. Nr. 1. pp. 83-88

UNWTO (2015): Tourism Highlights. 2015 th edition. World Tourism Organization. http://www.e-unwto.org/doi/pdf/10.18111/9789284416899

UNWTO(2016):http://media.unwto.org/press-release/2016-01-18/international-tourist-arrivals-4-reach-record-12-billion-2015

Új Széchenyi Terv (2011).

http://www.polgariszemle.hu/app/data/Uj_Szechenyi_Terv.pdf

Ráthonyi G. G. (2013): Influence of social media on tourism - especially among students of the University of Debrecen, APSTRACT Applied Studies in Agribusiness and Commerce Vol. 07 Nr 1, pp.105-112.

Ráthonyi G. G. - Ráthonyi-Odor K. - Várallyai L. - Botos Sz. (2016): Influence of social media on holiday travel planning, Journal of Ecoagritourism Vol.12. Nr.1. pp. 57-62.

Scherhag, K. (2000): Profilierungsstrategien für touristische Regionen. Fontanari, M. - Scherhag, K. (ed): Wettbewerb der Destinationen. 158. p.

WTTC (2015): Travel and Tourism. Economic Impact 2014. World Travel and tourism Council. https://www.wttc.org/-/media/files/reports/economic\%20impact\%20research/regional\%202015/world2015. pdf 